\title{
VIOLÊNCIAS E ESCOLA: PRÁTICAS DO \\ COTIDIANO DE UMA ESCOLA PÚBLICA \\ ESTADUAL
}

Daiana Cristina Sebenello*

Irme Salete Bonamigo**

Resumo: Apresenta um estudo desenvolvido no curso de Psicologia da Universidade Comunitária da Região de Chapecó (Unochapecó) que procurou identificar práticas violentas presentes no cotidiano de uma escola pública estadual na cidade de Chapecó, Santa Catarina. A estratégia de pesquisa utilizada foi a pesquisa-intervenção, e os participantes do estudo foram atores da escola. $\mathrm{O}$ estudo integra dados qualitativos e quantitativos, utilizando os seguintes instrumentos de pesquisa: observação participante, grupos focais, entrevistas, análise de documentos, pesquisa hemerográfica e aplicação de questionários. Entre os resultados, a pesquisa identificou que a prática violenta mais frequente era a agressão verbal entre alunos, seguida das agressões físicas e ameaças. Foram identificadas também tensões na relação professor-aluno, sobressaindo-se no discurso dos professores o sentimento de impotência. Foi constatada a presença de gangues e a participação de alunos nesses grupos. A pesquisa concebeu estas práticas como construções sociais, problematizando-as e possibilitando reflexões voltadas à produção de outros sentidos e práticas.

Palavras-chave: Pesquisa-Intervenção. Violências. Escola. 
Abstract: It presents a study conducted in the course of Psychology of the Community University of the Region of Chapecó (Unochapecó), which sought to identify violent practices in the daily lives of a public school in the city of Chapecó, Santa Catarina. The chosen research strategy was the intervention-research, and the study participants were school actors. The study integrates qualitative and quantitative data, using the following research tools: participant observation, focus groups, interviews, document analysis, hemerographic research and questionnaires applications. Among the results, the research has identified that the practice between students was more frequent in violent verbal aggression kind, followed by physical assaults and threats. Also it was identified tensions among the teacherstudent relationship, excelling in the teachers with powerlessness feelings speeches. It was confirmed the presence of gangs and participation of students in those groups. The research has designed those practices such as social constructions, questioning them and allowing thoughts turned to the production of other meanings and practices.

Keywords: Intervention-research. Violences. School. 


\section{Introdução}

Abordar qualquer tema relacionado à categoria "violência" não é uma tarefa fácil, tendo em vista a dificuldade de delimitá-la conceitualmente e às práticas que historicamente a produzem. Pensar em violências na escola se torna uma tarefa mais árdua ainda, pois relacionamos a categoria violência a um espaço sócio-historicamente produzido como local de educação; nas palavras de Charlot (2002), um local considerado por muitos como "refúgio da paz".

A complexidade do tema desafia profissionais e pesquisadores, e diversos estudos são desenvolvidos para problematizar e debater a questão. Essa complexidade não diz respeito somente à categoria violência, mas também ao estabelecimento escolar como um todo. A análise das relações, das práticas que são constituintes deste local, também deve compor o debate e as reflexões sobre as violências nas escolas.

Nesse sentido, este artigo procura problematizar e discutir a temática "violências e escola". Os dados que serão apresentados foram obtidos por meio de uma pesquisa realizada no ano de 2009 em uma escola pública estadual na cidade de Chapecó, oeste de Santa Catarina; procurou-se identificar práticas violentas presentes no cotidiano dessa escola. No período de realização da pesquisa, aproximadamente 908 alunos estavam matriculados nos três turnos letivos da escola, e o quadro de professores e funcionários era de aproximadamente 34 profissionais. Não constam destes números as serventes do estabelecimento e uma guarda que atuavam na escola.

$\mathrm{O}$ artigo aborda os principais resultados desse estudo, apresentando inicialmente alguns conceitos referentes ao tema que dirigiram o estudo, o processo de construção dos dados e os partici- 
pantes da pesquisa, para posteriormente discutir os resultados a partir dos referencias teóricos escolhidos.

\section{Violências e escola}

De acordo com Bonamigo (2008), o que caracteriza um ato como violento varia histórica e culturalmente. Da mesma forma, Sposito (1998) expõe que o limite entre o reconhecimento ou não de um ato como violento é definido pelos atores em condições históricas e culturais diversas. Segundo ela, a definição de violência mais aceita e repercutida é a de que "[...] a violência é todo ato que implica na ruptura de um nexo social pelo uso da força." (SPOSITO, 1998, p. 3). No entanto, é importante ressaltar que esta definição não abarca determinadas práticas mais sutis e cotidianas, como o racismo e a violência simbólica, observadas em sala de aula.

De acordo com Bonamigo (2008), as modificações em nossa percepção e sensibilidade possibilitam hoje abranger novos tipos de violências que antes não eram considerados: discriminação por cor, sexo, idade, etnia, religião, escolha sexual, situações de constrangimento, exclusão ou humilhação. Debarbieux (2002) também sinaliza que, ao expandirmos a definição de violência, corremos o risco de criminalizar padrões comportamentais comuns, já uma definição excessivamente limitada pode excluir algumas práticas e a experiência de algumas vítimas.

Mas, então, o que exatamente se caracteriza como "violência"? Que práticas, especialmente as vinculadas ao contexto escolar, podem ser consideradas violentas? Para Bonamigo (2008), a denominação "violência" está hoje naturalizada, pois a mesma palavra 
é utilizada para diferentes situações e com diferentes significados, configurando-se um processo de generalização e homogeneização do fenômeno. Tendo em vista esses questionamentos, será empregado neste artigo o termo "violências", no plural, porque este possibilita apreender os sentidos que a categoria comporta no espaço de realização da pesquisa, entre os atores deste contexto, e assim evita a delimitação do conceito em uma definição fixada a priori.

\section{Método de pesquisa e a construção das informações}

A pesquisa-intervenção, referencial metodológico que guiou este estudo, baseia-se, conforme Rocha (2006), nos princípios da Análise Institucional Socioanalítica, corrente desenvolvida na França durante as décadas de 1960/1970, que possui como teóricos expoentes René Lourau e Georges Lapassade; e na Filosofia da Diferença, que possui como principais teóricos Gilles Deleuze e Félix Guattari.

Nesta metodologia de pesquisa, segundo Rocha (2006, p. 169), o conhecimento “[...] se constrói [...] entre o saber já elaborado e incorporado nos pressupostos do pesquisador e o fazer enquanto produção contínua que organiza a ação investigativa." Conceber que a produção de conhecimento ocorre nesta relação significa dizer, conforme Rocha (2006), que, ao mesmo tempo que se produzem as práticas que constituem o social, vão se produzindo os referenciais que lhes dão sentido.

O pesquisador necessita, então, compreender os efeitos das práticas em sua complexidade, "desconstruindo dualidades, determinismos, e individualizações psicologizantes" (ROCHA, 2006, p. 170). A visão crítica do pesquisador emerge dessa desnaturaliza- 
ção das práticas, dando visibilidade no processo de pesquisa às "rupturas, aos processos que ora afirmam, ora desmancham territórios cristalizados" (ROCHA, 2006, p. 170).

Como pesquisadores, nosso papel constitui-se, segundo Rocha (2006), em investigar os movimentos permanentes dos processos de subjetivação. Por isso, tendo em vista que o objetivo desta pesquisa é problematizar o tema violências na escola, procuramos acompanhar as relações que ocorrem nesse contexto, os processos de subjetivação hegemônicos e as diversas expressões dos processos de singularização.

Para compreendermos as relações nesse contexto da pesquisa, utilizamos como técnicas entrevistas, grupos focais, aplicação de questionário, pesquisa documental, pesquisa hemerográfica em jornais de circulação local, além da observação participante e elaboração de diário de campo. Essas técnicas utilizadas permitiram a construção de dados qualitativos e quantitativos, que foram reunidos neste estudo. Aliando a pesquisa qualitativa e quantitativa, utilizamos o procedimento metodológico misto, que permite, de acordo com Creswell (2007), a ampliação da discussão sobre um problema de pesquisa, pois incorpora tanto a necessidade de explorar quanto a de compreender.

Desde o início do desenvolvimento da pesquisa, no primeiro contato com a escola, foram realizadas várias conversas informais, presenciadas e vivenciadas várias situações; registradas em diário de campo, elas constituem, conforme Flick (2004), a observação participante. A observação participante possibilita, segundo Cruz Neto (1999, p. 60), “[...] a compreensão de uma variedade de situações ou fenômenos que não são obtidos por outros meios, pois observados na própria realidade, transmitem o que há de mais imponderável e evasivo na vida real.” Na prática da pesquisa, isso 
ocorreu em conversas informais com professores, funcionários, alunos e moradores próximos à escola. Momentos como a participação na assembleia de pais, na eleição para a escolha da direção da escola, intervalos de aula frequentando a sala dos professores, entre outros, proporcionaram esse acesso ao campo e o vínculo com os participantes da pesquisa.

Tudo era anotado no diário de campo, o que ouvíamos, víamos, falávamos e também o que sentíamos. $\mathrm{O}$ diário de campo, enfatiza Fernandes (2002), ordena através do fio narrativo a dispersão dos acontecimentos do cotidiano, não apenas o que era de caráter descritivo, mas as cognições e sentimentos que constantemente se produzem no contato com a vida social do local.

Para Flick (2004), esse processo de envolvimento com o campo é considerado crucial na pesquisa, isso porque o pesquisador não pode perder de vista sua perspectiva crítica, para visualizar o particular naquilo que faz parte do cotidiano e da rotina do local e não adotar incondicionalmente os pontos de vista do campo. Ao tratar desse tema, Flick (2004) abre espaço para discutirmos uma das principais ferramentas da pesquisa-intervenção que auxilia nas reflexões sobre a relação pesquisador e pesquisado: a análise das implicações.

Partindo do princípio de que não existe neutralidade do pesquisador no ato de pesquisar, Paulon (2005) aponta que o observador, por definição, transforma o seu objeto de estudo e desta maneira surge a necessidade de ele incluir-se no processo investigativo. Trata-se na pesquisa, conforme Santos e Barone (2007), de realizar a análise das relações que estabelecemos com o objeto de pesquisa, com a instituição da pesquisa, com as instituições de pertencimento (social, político, econômico, profissional), com as demandas produzidas, com as práticas do contexto pesquisado e com as formas de conhecimento. 
No cotidiano da realização da pesquisa na escola, percebemos que muitas vezes nos colocávamos no lugar dos alunos, e pensávamos como era difícil ficar em silêncio em sala de aula, ou não brigar com determinados colegas que nos chateavam. Por outro lado, em outros momentos parecia que tínhamos nos tornado professores, quando compartilhávamos com eles raivas e angústias por não conseguirem explicar conteúdos, ou pela má remuneração de seu trabalho.

Na escola, também tivemos contato com estagiárias de outros cursos, e delas ouvimos o desabafo: "a escola está cansada de estagiários". Colocamo-nos no mesmo lugar, compartilhando as dificuldades encontradas na relação com atores desse contexto. Foi preciso muito tempo e paciência para construirmos um vínculo que possibilitasse a realização da pesquisa. Por outro lado, percebemos que nessa relação de poder a escola como um todo é destituída de saber.

A Nutrição vem dizer o que comer, como comer, quando comer, como as serventes devem preparar os alimentos. E a Psicologia vem observar, dizer como devem lidar com os alunos, como os alunos devem agir com os colegas, com os professores. Novamente estamos no lugar dos experts, dizendo de que forma as pessoas devem viver o seu cotidiano. (Trecho do Diário de Campo da primeira autora, 24 mar. 2009).

Além dos dados construídos a partir das observações, foram realizados três grupos focais, um com professores e dois com alunos. De acordo com Gaskell (2002), o grupo focal possibilita uma interação mais autêntica do que a entrevista, pois no grupo os sentidos ou representações que emergem são mais influenciados 
pela natureza social da interação do grupo, e não somente pela perspectiva individual.

Foram três grupos focais: o primeiro contou com a participação de três alunos; o segundo, com a participação de seis alunos; e o terceiro foi realizado com sete professores da escola. Para complementar alguns dados que surgiram a partir das observações e dos grupos focais, foram realizadas três entrevistas, uma com um policial que atua na região onde está localizada a escola, outra com o ex-diretor da instituição, que atuava no ano de 2008, e uma com um pai de aluno da escola.

A pesquisa de documentos contou com a observação de fichas de registros da escola, onde são anotadas situações de indisciplinas e encaminhamentos tomados. Foi coletada também uma cópia de normas de convivências da escola, documento que foi distribuído aos alunos no início do ano letivo de 2009.

Já a pesquisa hemerográfica foi realizada no período entre outubro de 2008 e fevereiro de 2009. Foram coletadas reportagens sobre o tema de pesquisa de quatro jornais de circulação local Diário do Iguaçu, Sul Brasil, Folha de Chapecó e Voz do Oeste.

$\mathrm{O}$ questionário possibilitou o mapeamento de determinadas práticas no contexto da escola estudada. Esse instrumento foi aplicado a um total de 150 alunos da escola; entre professores e funcionários da escola, foram seis respondentes. As práticas foram avaliadas de acordo com sua frequência: "sempre"; "às vezes"; "raramente"; "nunca”. O questionário era constituído por 27 questões, divididas nos seguintes blocos: Agressões verbais: xingamentos, deboches etc. (três questões); Agressões físicas leves (três questões); Agressões físicas com atendimento médico (três questões); Ameaças (três questões); Violência contra o patrimônio escolar 
(duas questões); Delitos (sete questões); Segurança (uma questão); Presença da polícia (uma questão); Relação escola-família (uma questão); Assédio sexual (duas questões); Inclusão de outras práticas violentas (uma questão).

A pesquisa-intervenção, referencial metodológico escolhido, possibilitou discussões ampliadas sobre o tema, por problematizar noções naturalizadas na pesquisa, como a de neutralidade e objetividade do pesquisador. A partir desse referencial, foi possível ainda investigar os processos permanentes de subjetivação, dando visibilidade na pesquisa aos movimentos, às rupturas, aos desvios que as ações individuais e coletivas imprimem no cotidiano (ROCHA, 2006). Em virtude da complexidade e da abrangência do tema, apresentaremos, neste artigo, apenas alguns dos resultados da pesquisa.

\section{Relação entre os alunos}

Entre as múltiplas manifestações que justificam falar em violências na escola, estão as agressões verbais entre alunos. As agressões verbais compreendem xingamentos, deboches, insultos, palavras afrontosas de uma pessoa para outra, e podem ser faladas ou escritas. Esta é a prática mais frequente no cotidiano da escola estudada de acordo com os respondentes do questionário aplicado. Para 88 alunos (58\%) respondentes do questionário, essas práticas são comuns e ocorrem "às vezes” na escola. Esses dados se assemelham aos obtidos no questionário aplicado com professores e funcionários. Para três dos seis respondentes, esta prática ocorre "sempre", para dois respondentes ocorre "às vezes" e ainda uma pessoa não assinalou nenhuma opção. 
O xingamento entre alunos é considerado pelos participantes do grupo focal como algo banal. Na escola estudada, os xingamentos são variados e podem ser observados também em pichações no banheiro feminino da escola: "T. 201. Puta, galinha, chifruda; L. rasgada, puta, vaca; J. vaca, puta, rasgada”. As ameaças também são frequentes nas pichações no banheiro feminino: "G., C., C., J., Se cuidem suas vacas, vagabundas... Na hora de inticar vocês são né, mas na hora de brigar, cortam. Turma 71”. Elas aparecem como terceira prática violenta mais frequente, ficando atrás das agressões verbais e das agressões físicas leves entre alunos. Cerca de 50\% do total de respondentes do questionário (75 alunos) apontam que as ameaças ocorrem "às vezes” na escola.

Ao registrarem-se algumas ameaças, foi constatado que elas antecedem às brigas. As ameaças escritas no banheiro da escola, com frases como "se cuide", já sugerem a ocorrência de brigas. Para Ruotti (2006, p. 71), a ocorrência dessas ameaças indica “[...] uma tensão nas relações entre alunos, os quais muitas vezes procuram resolver do lado de fora da escola desavenças criadas dentro da escola."

A partir do questionário, as brigas aparecem como a prática violenta mais frequente entre alunos, ficando atrás somente das agressões verbais. Para 56\% do total de respondentes do questionário (83 alunos), as agressões físicas (tapas, empurrões, socos, pontapés, chutes, entre outros) entre alunos ocorrem "às vezes" na escola.

Para Alves (2006), se de certa forma é esperado que crianças se utilizem mais das agressões para tentarem resolver seus conflitos, espera-se que com o processo de socialização e educação esse comportamento seja reduzido. A escola, segundo este autor, é um dos espaços para desenvolver e aperfeiçoar o processo socializador e educativo; desta forma, espera-se que, à medida que o tempo de 
presença na escola vai aumentando, o comportamento que envolve agressões físicas seja substituído por outras formas de resolução de conflitos pacíficas.

Para Ruotti (2006), boa parte das brigas que ocorrem durante o intervalo ou na entrada e saída da escola teve seus motivos gerados ainda em sala de aula. Para a autora, são "[...] provocações, discussões e xingamentos que geram o denominado 'acerto de contas', que envolve frequentemente, agressão física." (RUOTTI, 2006, p. 96). Alves (2006) aponta que uma forma de minimizar as agressões físicas entre alunos seria desestimular as agressões verbais entre eles.

Mesmo quando a briga ocorre fora da escola, o estabelecimento escolar está relacionado, não somente pelo fato de os agentes da briga serem estudantes, mas também pelos encaminhamentos tomados pelo estabelecimento após as brigas. Como explica o Participante V: "Elas brigam lá fora, mas só que daí aquela gangue que perde sempre vem contar para os diretores."

O encaminhamento da escola nesse tipo de ocorrência depende da gravidade do fato, que é avaliada pela direção. O padrão de encaminhamentos é o mesmo descrito por Ruotti (2006): a direção decide, de acordo com o caso, chamar os pais ou responsáveis na escola, aplicar advertências, suspensões ou, em últimos casos, a "transferência compulsória", também conhecida como expulsão.

Neste caso, Alves (2006) aponta que, se por um lado a violência existente no entorno, muitas vezes esta invade, por outro lado, o espaço escolar, contribuindo para a sensação de insegurança nele, os conflitos gerados na escola, quando não encontram nela solução, podem levar a atos violentos fora do espaço escolar, contribuindo então para a violência e para a sensação de insegurança no bairro. 
Os motivos para as brigas são diversos, e para os participantes E, AI, D, AF, AG e M as brigas em sua maioria envolvem as meninas; porém, as brigas entre meninos são bem mais graves. Estas brigas envolvem tanto armas brancas (facas, estiletes, canivetes) quanto armas de fogo, e envolvem grupos da região onde a escola está localizada. Esses grupos de meninos que brigam entre si são denominados pelos participantes da pesquisa de gangues.

\section{O entorno da escola, as armas, as drogas e as gangues}

As armas são utilizadas pelos jovens, segundo Abramovay et al. (1999), para proteção em relação a brigas, assaltos e violência que fazem parte do seu cotidiano. Quando questionados sobre por que muitos jovens saem armados, os Participantes $\mathrm{R}$ e $\mathrm{Z}$ respondem que utilizam as armas por terem conflitos entre grupos, para "estarem preparados" caso alguma "encrenca" aconteça.

Nenhum dos participantes da pesquisa relatou ter visto algum aluno com arma de fogo dentro da escola, porém isso não se repete com as armas brancas, como facas, estiletes, entre outras. Segundo os dados do questionário, a presença de aluno armado "nunca ocorre" para a maioria dos respondentes, no total 84 pessoas (56\%); para 39 respondentes (26\%), ela ocorre "raramente". Essa prática é mais frequente para 17 respondentes (11\%) que apontam que ela ocorre "às vezes" na escola; para quatro respondentes (3\%), ela "sempre" ocorre.

Os conflitos entre grupos juvenis foram descritos no questionário aplicado com professores e funcionários da escola, em que um respondente escreveu no instrumento: "violência que acontece fora da escola, entre alunos e gangues do bairro". Segundo 
Abramovay (2002), a formação de gangues, que vão dos grupos de amigos, turmas de bairro, de quadra, até o grupo de bandidos (traficantes, assaltantes e ladrões), que em muitos casos contam com a presença de alunos entre seus membros, é agravante do clima de insegurança nos arredores das escolas.

Participante H: [...] que bom se tivesse só nas agressõezinhas lá fora, já superou isso, os adolescentes de oitava série, de segundo grau, já têm diferentes tipos de organização lá fora, as galeras, os grupos, as ameaças com arma de fogo, estas são situações, foi-se o tempo só da menininha que discutia com a outra por causa da cor do batonzinho.

Para Abramovay et al. (1999), o termo "gangue" é comumente empregado no Brasil para referir-se a um grupo de jovens, um conjunto de companheiros, uma organização juvenil ligada à delinquência. Segundo Diógenes (1998, p. 114), o termo é também utilizado pelos próprios grupos para “[...] intensificar e dar visibilidade para si e para os outros acerca do caráter, realmente violento [...] dos que a integram.” Essa designação também foi referida pelos participantes da pesquisa.

Seis grupos foram citados pelos participantes da pesquisa: os No Mala; os Smokers; os Cabeças; os Primos; e ainda dois outros grupos, os $P D V$ e os GDC. Estes últimos são apresentados somente com as iniciais, pois os nomes se referem aos locais ou bairros em que os jovens residem, e não serão descritos neste trabalho para que a escola estudada não seja identificada. Para Abramovay et al. (1999), as razões para o embate entre esses grupos podem ser inúmeras: um olhar, um esbarrão, atritos antigos, uma provocação, um deboche, uma rivalidade entre as turmas, não gostar do outro grupo, invasão de territórios e mulheres. 
Alguns integrantes desses grupos são alunos da escola. Segundo o Participante O: "Aqui na escola tinha a maioria No Mala e Smokers [nomes das gangues]." Ainda de acordo com o mesmo participante, cada grupo possui suas características, até mesmo com relação às armas que utilizam nas brigas: "Que nem os No Mala andam só de revólver pra brigar e os PDV com as facas. Cada um tem seu estilo, só que os Smokers não usam nada.”

A repercussão das práticas de gangues na região não diz respeito somente à ocorrência de brigas em frente à escola, está relacionada diretamente à permanência ou não dos jovens na escola. Segundo o Participante R, muitos jovens mudam de escola ou, ainda, param de estudar por causa das brigas entre esses grupos na região.

Para Sposito (2001), a rivalidade entre grupos juvenis, que se expressa na segmentação da região em unidades territoriais bastante conflituosas, causa perplexidade no grupo de professores e afeta a execução do projeto educativo da escola. Da mesma forma, Pinheiro (2006) aponta que as escolas são afetadas por eventos ocorridos na comunidade maior, pela incidência de cultura de gangues e de atividades criminosas relacionadas a gangues, por exemplo, o tráfico de drogas. $\mathrm{O}$ envolvimento dessas gangues citadas na pesquisa com o tráfico de drogas não foi confirmado por nenhum participante.

Conforme Abramovay (2002), a presença de traficantes nos arredores da escola, ou mesmo dentro delas, facilita e amplia o acesso dos jovens às drogas e, por consequência, aumenta a probabilidade do consumo destas. Na escola estudada, o tráfico de drogas é visto pela maioria dos alunos respondentes do questionário como uma prática pouco frequente, ou que não ocorre.

Para 107 respondentes (71\%), o tráfico de drogas "nunca" ocorre; para 27 respondentes (18\%) ocorre "raramente". Dez respon- 
dentes (7\%) afirmam que essa prática “às vezes” ocorre na escola, e para dois respondentes (1\%), um do período vespertino e outro do período noturno, ela é frequente, ocorrendo "sempre". Não há variações entre os turnos letivos, e no total quatro pessoas (3\%) não responderam essa questão.

O consumo de drogas também "nunca" ocorre para a maioria dos respondentes, 79 pessoas (53\%), e para 42 pessoas $(28 \%)$ essa prática ocorre "raramente". Mas, para 20 pessoas (13\%) ela é mais comum, ocorrendo "às vezes", e para dois respondentes (1\%) o consumo de drogas "sempre" ocorre na escola. Outros participantes (participantes AS, D e E) relatam que a escola é visada por traficantes que desejam se matricular nela para ter o acesso facilitado aos alunos, a fim de comercializar as drogas: “[...] não que necessariamente façam a venda dentro da escola, mas através da escola eles conhecem mais pessoas, contatos para vender depois fora da escola." (PARTICIPANTE D).

Uma das estratégias adotadas pela escola estudada para inibir a presença de traficantes no estabelecimento é impedir sua matrícula na escola, ou retirá-los por meio da transferência compulsória. Eles foram identificados porque pertenciam a gangues da região, tinham envolvimento com drogas e poderiam, segundo o Participante A, trazer a distribuição de drogas para a escola.

Após a realização da transferência desses alunos, a direção da escola sofreu ameaças por parte desses jovens. A casa do diretor da escola, que reside próximo ao estabelecimento, foi apedrejada. $\mathrm{O}$ diretor procurou a polícia, registrou uma ocorrência referente aos fatos e disse que teve apoio da comunidade escolar nesses momentos.

Para discutir esses fatos, utilizamos algumas distinções conceituais postuladas por Charlot (2002). Para a autora, as violências na 
escola podem ser distintas em três categorias: a violência na escola, a violência $d a$ escola e a violência à escola. A violência na escola é aquela que se produz dentro do espaço escolar, sem estar ligada à natureza e às atividades do local. Um exemplo desta é quando um grupo invade a escola para brigar com alguém que está nas dependências da escola, neste caso, a escola é invadida por uma violência que acontecia fora de seus portões ou na rua (CUBAS, 2006). Segundo Charlot (2002), a violência à escola ocorre quando as práticas violentas visam ao estabelecimento escolar ou a quem os representa, como quando os alunos provocam incêndios, batem ou insultam professores. E, por último, a violência $d a$ escola, que diz respeito a uma violência institucional simbólica, que os próprios alunos suportam por meio da maneira como a instituição e seus agentes os tratam. A autora traz vários exemplos que deixam clara esta forma de violência, como o modo de composição das classes, de atribuição de notas, de palavras desdenhosas ou atos injustos.

A violência do entorno escolar, como as rivalidades entre grupos de jovens, o tráfico e o consumo de drogas e álcool, é prática que não está necessariamente vinculada à prática pedagógica, e pode, portanto, ser considerada violência na escola. Essa distinção pode contribuir para identificar problemáticas e identificar ações e atores para o seu enfrentamento, como o que caberia a cada órgão e política pública para minimizar seus efeitos no contexto escolar, no entanto as práticas podem estar interligadas.

No caso citado anteriormente, a escola, ao impedir que determinadas pessoas se matriculassem, cometeu uma prática de violência da escola, pois excluiu essa parcela da comunidade do direito à educação. Ainda, nesse movimento de tentar impedir que o tráfico de drogas ocorresse naquele espaço, funcionários do estabelecimento foram vítimas de ameaças e danos a suas residências foram 
causados por parte de estudantes que, ao manifestarem agressão a pessoas que representavam o estabelecimento, cometeram violência à escola.

Assim, se coibir o tráfico de drogas pode ser considerada predominantemente uma tarefa de outros órgãos e políticas públicas, da mesma forma, outras práticas, como a indisciplina dos alunos, dizem respeito à escola e não à polícia. Na escola estudada, observamos uma situação que exemplifica este caso: um aluno que não fazia parte de determinado turno letivo estava no pátio da escola, conversando com um colega; um funcionário da escola solicitou que o aluno se retirasse e fez o seguinte comentário: "se você não sair eu vou chamar os 'home' para te tirar daqui'.

A presença dos pais na escola também foi abordada na pesquisa e, de acordo com os dados do questionário, a relação entre a família e a escola é frequente, ocorrendo "às vezes" para 76 respondentes (51\%), e "sempre" para 36 respondentes (24\%). Essa relação é menos frequente para 21 respondentes (14\%), que assinalaram a opção "raramente"; ela "nunca" ocorre para dez respondentes (7\%). Sete pessoas (4\%) não responderam a questão ou assinalaram duas ou mais alternativas.

Ruotti (2006) aponta que muitas vezes a família é considerada como a grande responsável pela indisciplina escolar, e a aproximação da família com a escola por meio de projetos é tida como um caminho para a minimização de práticas violentas nesse contexto. Porém, essa aproximação requer a reformulação de práticas na escola, pois, como aponta o pai entrevistado, os pais querem expor suas opiniões, querem participar de decisões da escola. A inclusão de pais, de professores e dos próprios alunos nas decisões da escola, como na elaboração de normas, discutindo e estabele- 
cendo direitos e deveres dos diferentes membros escolares, perpassa o que Ruotti (2006) denomina de democratização da gestão.

No período de realização da pesquisa, ficamos sabendo que a escola havia sido invadida por um grupo de jovens no período das férias. Esses jovens pularam o muro da escola e foram até o seu ginásio para jogar futebol. Este fato aponta para a necessidade dos jovens dessa região por espaços de lazer, praticamente inexistentes.

Práticas como aumentar os muros da escola e fechar o ginásio escolar para uso externo distanciam ainda mais a escola da comunidade e demonstram, de acordo com Alves (2006), o caráter simplista das políticas públicas nesse contexto. Para este autor, são necessárias ações conjuntas de diferentes áreas e esferas dos poderes públicos no estabelecimento de outras políticas públicas voltadas à população, especialmente aos jovens dessa região.

\section{Relação entre alunos e professores e/ou funcionários}

As agressões verbais entre alunos e professores também ocorrem, mas em menor proporção do que a verificada na relação entre alunos. No total, a maioria dos respondentes, 59 alunos (39\%), avaliou que as agressões verbais entre alunos e professores ocorrem "raramente" na escola. Mas para 53 respondentes (35\%) essa prática ocorre "às vezes", demonstrando uma pequena diferença, um total de seis alunos, entre ambas as opções. Com relação à agressão verbal entre alunos e funcionários, a grande maioria dos respondentes, oitenta pessoas (53\%), sugere que essa prática "nunca” ocorre. Não existem variações de respostas significativas entre os turnos, e esta opção ("nunca”) é a mais frequente, totalizando 
$50 \%$ (24 pessoas) no período noturno, e de 54\% no vespertino (23 pessoas) e no matutino (33 pessoas).

Esses dados indicam a existência de algumas tensões na relação professor e aluno. Em sua pesquisa, Ruotti (2006) percebeu que os motivos destas são geralmente a bagunça ou o desrespeito que os alunos demonstram para com os professores por meio de provocações, xingamentos ou desobediência.

Com relação às agressões verbais de professores em relação aos alunos, a Participante V disse que elas ocorrem: "Eles chamam a gente de burrinha, ignorante, essas coisas assim." Para o Participante $\mathrm{M}$, as agressões realmente ocorrem e ele as justifica dizendo:

[...] a violência às vezes, na questão verbal, às vezes ela se manifesta da nossa parte também com o aluno [...] chega um momento que às vezes você perde a paciência, perde a paciência até de chamar a atenção deles com educação. [...] E às vezes você usa também palavrões pra xingá-los, essa violência por parte nossa em relação a eles também ocorre, também ocorre.

Segundo os Participantes Z e V, o encaminhamento dado pela direção nos casos de agressões verbais entre alunos e professores favorece o professor: "E daí quando a gente fala alguma coisa pra eles, o diretor não acredita na gente, quem tem a razão é o professor, é sempre assim, nunca acontecem as coisas diferentes." (PARTICIPANTE Z).

Esse tipo de situação foi identificado em outras falas de outros participantes da pesquisa e demonstra como predominam nas escolas relações verticalizadas, hierarquizadas e autoritárias. Os alunos são impedidos muitas vezes de manifestar suas opiniões, de se defenderem, de descreverem o que aconteceu, sendo as solu- 
ções desprovidas de qualquer possibilidade de diálogo (ANSARA; COSTA, 2009).

Da mesma forma, para o Participante P existe pouca abertura por parte de alguns professores para o questionamento dos alunos. Quando questionado sobre como poderiam ser as aulas, o participante respondeu: "Que nem a de História, ela comenta e deixa a gente falar, se não está certo daí ela fala." O diálogo entre o professor e o aluno em sala de aula possibilita, conforme Kohatsu e Dias (2009), que a aprendizagem ocorra em uma relação de troca, e não somente de repasse de informações de um para o outro, quando o conhecimento é convertido em mercadoria a ser adquirida e vendida.

Alves (2006) constatou, em sua pesquisa, que muitas vezes os professores evitam debates ou diálogos com os alunos porque os debates podem gerar situações de conflito na sala de aula. Mas essas situações são, para o autor, inevitáveis, tendo em vista que a própria relação professor e aluno é potencialmente conflituosa. Isso ocorre porque tal relação implica o encontro de diferentes saberes (o saber do professor e o saber do aluno) e diferentes temporalidades (o passado e o presente).

Nesse caso, Alves (2006) ressalta que o conflito não deve ser visto como sinônimo de violência: pode ser um dos desdobramentos desta, mas não o único possível. Para Rocha e Aguiar (2003), devemos compreender os conflitos e tensões como possibilidades de mudanças, possibilidades de desmanchar territórios cristalizados no contexto da escola.

Da mesma forma, para Ansara e Costa (2009), é necessário criar espaços na vida escolar que permitam o reconhecimento da diferença, a emergência do conflito e de práticas de negociação 
para a sua resolução, seja na relação entre alunos, seja na relação entre alunos e professores. A questão estaria, então, segundo Alves (2006), não em como evitar os conflitos, mas em como eles podem ser encaminhados e resolvidos a partir da própria ação pedagógica.

Santos (2001, p. 110) descreve que o caminho para a resolução desses conflitos perpassa práticas baseadas no “[...] diálogo, paciente, obstinado, pedagógico, que instauram o respeito pelo outro, que podem ajudar a eliminar a violência na escola." Da mesma forma, para Ansara e Costa (2009), onde há dialogo, onde há participação, as práticas de violência vão, aos poucos, atenuando e se dissolvendo.

Na fala, já citada anteriormente, do Participante $\mathrm{N}$, tem-se que na realidade de muitos alunos não existe o diálogo, não existe a conversa. Quando muitos professores falam da realidade dos alunos referem-se às relações familiares: "Então aí os nossos alunos não sabem mais conversar, em qualquer ambiente, lá em casa não se conversa mais, não dialogam mais, então eles não aprendem, não sabem o que é isso." (PARTICIPANTE N).

As explicações, por parte de alguns professores participantes da pesquisa, para a presença de práticas violentas na escola estão associadas à "família, que está desestruturada”. Para o Participante M: "A maioria dos alunos que têm problema, que a gente chama, vem a mãe. São filhos de pais separados, pais separados e que os filhos ainda presenciam muitas brigas entre os pais, sabe, que tem desentendimento, ou que tem problema com o pai." Esta explicação constitui o que Pimentel (2009) aponta como viés psicologizante, em que o diagnóstico do problema do aluno está atrelado à relação ou condição familiar, como ausência de orientação e de 
limites ou desestruturação do ambiente familiar.

Se para os professores o diálogo não está presente nas relações familiares de muitos alunos, e desta forma o aluno não aprende a conversar, perguntamos: a escola se constitui como um espaço onde o diálogo possa ocorrer? É possível na escola aprender a dialogar? E o que dizer com relação aos casos dos alunos que passam mais tempo na escola do que com a família?

Nesse caso, muitas vezes as explicações são buscadas nas condições sociais dos alunos, e no binômio, descrito por Pimentel (2009), da pobreza-violência. Mas esta autora questiona: como explicar então a violência em escolas particulares e de classe média e alta? Deparamo-nos, neste momento, com outra forma de explicar o fenômeno: o viés sociologizante. Nesse viés, a escola e seus atores são transformados em reféns de coordenadas que ultrapassam seu campo de ação, ficando somente a resignação, o desconforto e a desresponsabilização, porque "[...] a raiz do fenômeno e, por sua extensão, seu manejo residem fora dos muros escolares." (PIMENTEL, 2009, p. 80).

Tanto as explicações psicologizantes quanto as sociologizantes colocam a raiz do fenômeno da violência no seu exterior, e são, de acordo com Pimentel (2009), explicações totalizantes. Essas explicações, segundo a autora, mascaram o fato de que o surgimento ou o agravamento da violência geralmente ocorrem de forma concomitante e interligada a processos de discriminação, preconceito e violência no interior do próprio processo de escolarização.

Para Pimentel (2009), o cotidiano das instituições não opera totalmente à revelia dos desígnios dos seus atores, nem suas ações se constituem a reboque de forças macroestruturais abstratas. A 
escola, então, não é nem reprodutora, nem transformadora social, mas pode se converter em espaço de resistência pela reflexão.

Convenhamos, é mais do que evidente que as relações escolares não implicam um espelhamento imediato daquelas extra-escolares. Ou seja, não é possível sustentar categoricamente que a escola tão somente 'reproduz' vetores de forças exógenos a ela. É certo, pois, que algo de novo se produz nos interstícios do cotidiano escolar, por meio da (re)apropriação de tais vetores de força por parte de seus atores constitutivos e seus procedimentos instituídos/instituintes. (AQUINO, 1998, p. 10).

Para De Paula (2009), se pensamos a violência como algo que pertence a instâncias alheias ao nosso domínio, acabamos deixando, para estas mesmas instâncias, a responsabilidade ou a possibilidade de fazer algo a respeito, emergindo assim um sentimento de impotência e de incapacidade diante do fenômeno. Em algumas falas, professores participantes da pesquisa descreveram o sentimento de impotência diante das práticas.

Ao apontar-se que a escola, assim como as suas práticas, não ocorre à revelia de seus atores, não se está a dizer que a responsabilidade delas está exclusivamente no professor, que é apenas um dos polos da relação. Para Patto (2005), os professores também são vítimas da violência do descaso dos governantes pela educação pública. Essa violência pode ser visualizada nas más condições de trabalho destes profissionais: os baixos salários, que obrigam a maioria a um número alto de horas-aula semanais; a exclusão dos centros decisórios, os projetos são impostos de cima para baixo, da noite para o dia, diferentes a cada novo governo.

A preocupação desses profissionais está voltada à indisciplina do aluno, que de acordo com eles pode ser combatida com o 
resgate da autoridade do professor na escola, como podemos visualizar nas falas de dois participantes: "Porque eu acredito que o professor não é mais autoridade na escola, e ele tem que voltar a ser autoridade." (PARTICIPANTE G); "O professor hoje quer a condição para dar aula, para fazer seu trabalho, o professor, ele quer o resgate de sua autoridade." (PARTICIPANTE H).

Cabe lembrar que o professor, à medida que representa o saber acumulado perante gerações, possui um poder, e consequentemente é uma autoridade perante o aluno. A questão que se coloca é que, muitas vezes, o professor sente a necessidade de garantir esse seu lugar de autoridade por meio da manutenção da ordem, mas a diversidade de elementos que compõem a sala de aula impede a tranquilidade e a permanência nesse lugar (PIMENTEL, 2009).

Para Prata (2005), a crise da autoridade docente aponta a falência de um modelo de instituição calcado na ideia de disciplina. Conforme esta autora, o discurso dos professores e o diagnóstico feito por estes acerca da rebeldia do aluno partem do modelo do poder disciplinar a que eles, professores, foram sujeitados. Para Hardt e Negri (2001), neste modelo, amplamente discutido por Foucault, a sociedade é constituída por uma rede difusa de dispositivos que produzem os costumes, os hábitos e as práticas produtivas, por meio de instituições disciplinares: as prisões, os hospitais, a fábrica, a escola, entre outras. O poder disciplinar se manifesta então “[...] na estruturação de parâmetros e limites do pensamento e da prática, sancionando e prescrevendo comportamentos normais ou desviantes." (HARDT; NEGRI, 2001, p. 42).

Na sociedade disciplinar, segundo Prata (2005), o indivíduo passava linearmente pelas várias instituições, e cada uma delas possuía suas próprias regras e lógicas de subjetivação. Mas, hoje, o 
que podemos acompanhar, de acordo com esta autora, é a produção de um outro modo de se subjetivar, que também está presente na escola. Tanto os professores quanto os alunos afetam e são afetados pelo mesmo processo de subjetivação: “[...] uma mudança no modo pelo qual o poder marca seu espaço de circunscrição.” (PRATA, 2005, p. 113).

Essas mudanças nas técnicas de poder constituem as sociedades de controle. Conforme Prata (2005), a produção da subjetividade na sociedade de controle não se limita a um espaço exclusivo, nem a uma instituição específica. Para Hardt e Negri (2001), esse controle se estende para fora dos locais estruturados mediante redes flexíveis e flutuantes, e o poder é expresso como um controle que se estende pelas profundezas da consciência e dos corpos da população. Denominado por Foucault de "biopoder”, “[...] ele regula a vida social por dentro, acompanhando-a, interpretando-a, absorvendo-a e a rearticulando." (HARDT; NEGRI, 2001, p. 43).

A partir dessas análises, Prata (2005, p. 114) destaca que:

Mais do que um desencontro entre gerações distintas, o que se apresenta aqui é um processo de transformação social que abarca a instituição escolar e seus agentes. Dessa maneira, conforme coloca Aquino (1996a), a indisciplina pode estar indicando o impacto do ingresso de um novo sujeito histórico, com outras demandas e valores, numa ordem arcaica e despreparada para absorvê-lo.

Ainda conforme Leme (2009), a própria escola não se constitui mais como única forma de acesso ao conhecimento, que está disponível em qualquer hora e local por meio da rede mundial de computadores e de outros meios de comunicação. Uma das queixas dos professores é o interesse maior dos alunos por espaços como as lan houses do que propriamente pela escola. 
O ambiente escolar também, segundo Pimentel (2009), já não corresponde aos anseios dos jovens porque ascender socialmente a partir do que é oferecido pelo sistema de ensino tem possibilidades cada vez mais reduzidas. Estudos recentes demonstram que o aumento da escolaridade não significa melhores condições de absorção pelo mercado de trabalho, no qual há mecanismos próprios de produção de desigualdade e exclusão. Para Kohatsu e Dias (2009), os empregos em sua maioria não fazem uso daquilo que a escola oferece como conteúdo; existe uma oferta de empregos sem ocupação, cujo nível de escolaridade é incompatível com a função a ser exercida.

Para Santos (2009), existe um mito sobre a função social da escola como instituição salvadora, cuja missão é tirar das ruas crianças e jovens, ensinar-lhes princípios de moral e fornecer-lhes um diploma ilusório que não é capaz de garantir um lugar no mercado de trabalho em tempos de desemprego estrutural e de formas produtivas flexibilizadas e desregulamentadas.

Percebemos, então, que as noções socialmente construídas que sustentaram a escola como instituição estão sendo contestadas. Abramovay e Avancini (2004) salientam que a escola deixou de ser a única ou a principal fonte de transmissão de conhecimento, e que ela não prepara mais para o mercado de trabalho. Essas contradições são percebidas pelos jovens alunos, e o desinteresse deles por frequentar o estabelecimento aparece como uma preocupação dos professores: "Então esses alunos que só vêm para segurar número, ou eles mataram aula, [...] não sei, o que eles buscam aqui na escola? Aí, quando eles não estão comprometidos, eles aprontam.” (PARTICIPANTE N).

A pergunta e a constatação feitas pelo Participante $\mathrm{N}$ nos remetem para questões importantes que nos movem em busca da 
construção de novos conhecimentos: qual o sentido da escola na atualidade? $\mathrm{O}$ que as crianças e os jovens buscam hoje nesse local? Como a escola poderia promover em seu interior possibilidades de emancipação? Como a Psicologia poderia contribuir para essa produção de sentidos e emancipação?

\section{Considerações finais}

A escola é um local de permanente conflito, contradição e negociação. A complexidade desse estabelecimento ultrapassa seus muros, pois as relações que se estabelecem nesse contexto são produzidas a partir de dispositivos políticos, culturais, sociais, históricos e econômicos. A própria discussão sobre violência é bastante complexa, porque compreende um fenômeno multifacetado, intrincado e de difícil delimitação, que varia histórica e culturalmente.

Nesse momento histórico de intensas transformações, torna-se importante mantermos abertos os questionamentos para a produção de conhecimentos com base na configuração das problemáticas nas realidades em que elas acontecem. Acreditamos que somente a partir de estudos e reflexões que possibilitem a compreensão das relações e dos dispositivos em que as práticas sociais são forjadas possam ser produzidos outros sentidos e práticas diferenciadas.

Pesquisar violências no espaço escolar implica concebê-las e estudá-las como intrincadas a uma rede de atores e acontecimentos que lhe dão sentido e permitem-na circular. Quando conseguimos sair das explicações naturalizantes, tornamo-nos capazes 
de identificar, em nosso cotidiano, os dispositivos de produção das violências. Quando conseguimos localizá-las como parte integrante de nossas práticas, tornamos possível buscar e inventar outros modos de relação que produzam expressões outras, em que o conflito pode ser compreendido e abarcado como parte da ação pedagógica, com potencial para a afirmação do diálogo e para o reconhecimento e a afirmação das diferenças.

\section{Referências}

ABRAMOVAY, Miriam. Escola e violência. Brasília: Unesco, 2002.

; AVANCINI, Marta Franco. A violência e a escola: o caso Brasil. Brasília: Universidade Católica de Brasília, 2004. Disponível em: <http:// www.observatorio.ucb.unesco.org.br>. Acesso em: 21 set. 2008.

ABRAMOVAY, Miriam et al. Gangues, galeras, chegados e rappers: juventude, violência e cidadania nas cidades da periferia de Brasília. Rio de Janeiro: Garamond, 1999.

ALVES, Renato. As escolas em bairros com altas taxas de violência: a visão dos professores. In: RUOTTI, Caren; ALVES, Renato; CUBAS, Viviane Oliveira. Violência na escola: um guia para pais e professores. São Paulo: Andhep Imprensa Oficial do Estado de São Paulo, 2006. p. 109-149.

ANSARA, Soraia; COSTA, Giseli Paim. A violência no ambiente escolar: contribuições e desafios à Psicologia. In: DE PAULA, Fraulein Vidigal; D'AUREA-TARDELI, Denise (Org.). Violência na escola e da escola: desafios contemporâneos à psicologia da educação. São Bernardo do Campo: Universidade Metodista de São Paulo, 2009. p. 89-102.

AQUINO, Júlio Groppa. A violência escolar e a crise da autoridade docente. Cadernos Cedes, Campinas, ano 19, n. 47, p. 7-19, dez. 1998. 
BONAMIGO, Irme Salete. Violências e contemporaneidade. Revista Katálysis, v. 11, n. 2, p. 204-213, jul./dez. 2008.

- Violências na contemporaniedade: etnografia de redes sociotécnicas na cidade de Chapecó (SC). 2007. 410 f. Tese (Doutorado em Psicologia Social) - Universidade do Estado do Rio de Janeiro, Rio de Janeiro, 2007.

CHARLOT, Bernard. A violência na escola: como sociólogos franceses abordam essa questão. Sociologias, Porto Alegre, ano 4, n. 8, p. 432443, jul./dez. 2002.

CRESWEL, John W. Projeto de Pesquisa: métodos qualitativo, quantitativo e misto. 2. ed. Porto Alegre: Artmed, 2007.

CUBAS, Viviane de Oliveira. Violência nas escolas: como defini-la. In: RUOTTI, Caren; ALVES, Renato; CUBAS, Viviane de Oliveira. Violência na escola: um guia para pais e professores. São Paulo: Andhep Imprensa Oficial do Estado de São Paulo, 2006. p. 23-52.

DE PAULA, Fraulein Vidigal. Para uma escola sem violência: desvelando os nós de uma complexa rede. In: DE PAULA, Fraulein Vidigal; D'AUREA-TARDELI, Denise (Org.). Violência na escola e da escola: desafios contemporâneos à psicologia da educação. São Bernardo do Campo: Universidade Metodista de São Paulo, 2009. p. 113-124.

DEBARBIEUX, Eric. Violência nas escolas: divergências sobre palavras e um desafio político. In: ; BLAYA, Catherine (Orgs.). Violência nas escolas e políticas públicas. Brasília: Unesco, 2002. p. 59-92.

DIÓGENES, Glória. Cartografias da cultura e da violência: gangues, galeras e o movimento hip hop. São Paulo: Annablume, 1998.

FERNANDES, Luís. Um diário de campo nos territórios psicotrópicos: as facetas da escrita etnográfica. In: CARIA, Telmo H. (Org.). Experiência etnográfica em Ciências Sociais. Porto Alegre: Afrontamento, 2002. p. 23-40.

FLICK, Uwe. Uma introdução à pesquisa qualitativa. 2. ed. Porto Alegre: Bookman, 2004. 
GASKELL, George. Entrevistas individuais e grupais. In: BAUER, Martin W.; GASKELL, George. Pesquisa qualitativa com texto, imagem e som: um manual prático. Petrópolis: Vozes, 2002. p. 64-89.

HARDT, Michael; NEGRI, Antonio. Império. São Paulo: Record, 2001.

KOHATSU, Lineu N.; DIAS, Marian A. L. Sociedade e escola: produção e resistência à violência. In: DE PAULA, Fraulein Vidigal; D'AUREATARDELI, Denise (Orgs.). Violência na escola e da escola: desafios contemporâneos à psicologia da educação. São Bernardo do Campo: Universidade Metodista de São Paulo, 2009. p. 25-36.

LEME, Maria Isabel da Silva. Olhares sobre a violência e a escola: síntese e perspectivas. In: DE PAULA, Fraulein Vidigal; D’AUREATARDELI, Denise (Orgs.). Violência na escola e da escola: desafios contemporâneos à psicologia da educação. São Bernardo do Campo: Universidade Metodista de São Paulo, 2009. p. 125-135.

CRUZ NETO, Otávio. O trabalho de campo como descoberta e criação. In: DESLANDES, Suely Ferreira et al. Pesquisa Social: teoria, método e criatividade. 13. ed. Petrópolis: Vozes, 1999.

PATTO, Maria Helena Souza. Violência nas escolas ou violência das escolas? In: Exercícios de indignação: escritos de Educação e Psicologia. São Paulo: Casa do Psicólogo, 2005.

PAULON, Simone Mainieri. A análise de implicação como ferramenta na pesquisa-intervenção. Revista Psicologia \& Sociedade, v. 17, n. 3, p. 18-25, set./dez. 2005.

PIMENTEL, Alessandra. Os sentidos da violência escolar. In: DE PAULA, Fraulein Vidigal; D’AUREA-TARDELI, Denise (Orgs.). Violência na escola e da escola: desafios contemporâneos à psicologia da educação. São Bernardo do Campo: Universidade Metodista de São Paulo, 2009. p. 77-87.

PINHEIRO, Paulo Sérgio. Direitos das Crianças: relatório do especialista independente para o estudo das Nações Unidas sobre violência contra crianças. Assembléia Geral das Nações Unidas: UNICEF, 2006. Disponível em: <http://www.unicef.org/brazil/pt/Estudo_PSP_Portugues.pdf $>$. 
Acesso em: 22 abr. 2009.

PRATA, Maria Regina dos Santos. A produção da subjetividade e as relações de poder na escola: uma reflexão sobre a sociedade disciplinar na configuração social da atualidade. Revista Brasileira de Educação, n. 28, p. 108-115, jan./fev./mar./abr. 2005.

ROCHA, Marisa Lopes da. Psicologia e as práticas institucionais: a pesquisa-intervenção em movimento. Revista Psico, Rio de Janeiro, v. 37, n. 2, p. 169-174, maio/ago. 2006.

; AGUIAR, Kátia Faria de. Pesquisa-intervenção e a produção de novas análises. Revista Psicologia Ciência e Profissão, Brasília, v. 23, n. 4, p. 64-73, dez. 2003.

RUOTTI, Caren. Conflito e insegurança escolar nas zonas leste e sul do município de São Paulo. In: ; ALVES, Renato; CUBAS, Viviane de Oliveira. Violência na escola: um guia para pais e professores. São Paulo: Andhep Imprensa Oficial do Estado de São Paulo, 2006. p. 55105.

SANTOS, José V. T. dos. A violência na escola: conflitualidade social e ações civilizatórias. Revista Educação e Pesquisa, São Paulo, v. 27, n. 1, p. 105-122, jan./jun. 2001.

SANTOS, Nair Iracema Silveira dos; BARONE, Luciana Rodriguez. Uma pesquisa-intervenção em análise: militância, sobreimplicação ou ato político? In: MACHADO, Adriana Marcondes. Novos possíveis no encontro da Psicologia com a Educação. São Paulo: Casa do Psicólogo, 2007. p. 67-86.

SANTOS, Sheila Daniela Medeiros dos. O impacto da violência na educação escolar: desafios que se abrem à sociedade contemporânea. In: DE PAULA, Fraulein Vidigal; D’AUREA-TARDELI, Denise (Orgs.). Violência na escola e da escola: desafios contemporâneos à psicologia da educação. São Bernardo do Campo: Universidade Metodista de São Paulo, 2009. p. 11-24.

SPOSITO, Marilia Pontes. A instituição escolar e a violência. Instituto de Estudos Avançados da Universidade de São Paulo. Cadernos de 
Pesquisa. São Paulo: Fundação Carlos Chagas, p. 1-18, 1998. Disponível em: <http://www.iea.usp.br/observatorios/educacao>. Acesso em: 25 maio 2008.

Um breve balanço da pesquisa sobre violência escolar no Brasil. Revista Educação e Pesquisa, São Paulo, v. 27, n. 1, p. 87-103, jan./jun. 2001.

\section{Notas}

* Psicóloga graduada pela Universidade Comunitária da Região de Chapecó (Unochapecó), servidora pública municipal de Chapecó, pós-graduanda em Proteção de Direitos e Trabalho em Rede na Unochapecó, cursando Impactos da Violência na Saúde pela ENPS/Fiocruz. E-mail: < daiasebenello@gmail.com>.

** Doutora em Psicologia Social pela Universidade do Estado do Rio de Janeiro (UERJ), docente do Programa de Pós-Graduação Mestrado em Políticas Sociais e Dinâmicas Regionais e do Curso de Psicologia da Universidade Comunitária da Região de Chapecó (Unochapecó). E-mail: <bonamigo@unochapeco.edu.br>. 
